\title{
Biological control of the tomato wilt caused by Clavibacter michiganensis subsp. michiganensis using formulated plant growth-promoting bacteria
}

\author{
Kamal A. M. Abo-Elyousr ${ }^{1,2^{*}}$ (D), Hadeel M. M. Khalil Bagy ${ }^{1}$, Mohamed Hashem ${ }^{3,4}$, Saad A. M. Alamri ${ }^{3}$ and
} Yasser S. Mostafa ${ }^{3}$

\begin{abstract}
Rhizobacteria have been reported as bioagents of bacterial diseases and plant growth promoters. The present in vitro study and greenhouse experiment aimed to evaluate the efficiency of Bacillus subtilis, B. amyloliquefaciens, Pseudomonas fluorescens, and P. aeruginosa for the control of bacterial wilt caused by Clavibacter michiganensis subsp. michiganensis and promoting the growth of tomato plants. Effect of formulated and cell suspensions on disease reduction and the pathogen colonization frequency in plants were assessed. The tested bacterial species were able to inhibit the growth of the causal pathogen in vitro. Under greenhouse conditions, the highest reduction in disease severity was detected in tomato plants treated with formulated B. amyloliquefaciens (74.4\%), followed by $P$. aeruginosa (66.7\%), while the lowest reduction occurred in tomato seedlings treated with cell suspensions of $P$. fluorescens (40\%) and B. subtilis (53.3\%). The four bacterial species produced siderophores, hydrogen cyanide and indole acetic acid in different concentrations. The study confirmed that the use of the four bacterial species as suspensions or formulations could be applied as future eco-friendly alternatives to the synthetic fungicides for controlling the bacterial wilt of tomato caused by C. michiganensis subsp. michiganensis.
\end{abstract}

Keywords: Bacterial tomato wilt, Clavibacter michiganensis subsp. michiganensis, Biocontrol, Formulations

\section{Background}

Tomato (Lycopersicon esculentum L.) is a crop widely grown all over the world. It is a valuable agricultural commodity for food and a financial source for many low-income countries and can be cultivated under a wide range of climatic conditions and in many types of soil (Regassa et al. 2016). Disease management remains a major challenge in tomato production in many parts of the world. There are about 200 known tomato diseases of diverse causes and etiologies (Jones et al. 1991). Among them, the bacterial wilt disease caused by the bacterium, Clavibacter michiganensis subsp.

\footnotetext{
* Correspondence: kaaboelyousr@agr.au.edu.eg

${ }^{1}$ Faculty of Agriculture, Plant pathology Department, Assiut University, Assiut 71526, Egypt

${ }^{2}$ Department of Arid Land Agriculture, Faculty of Meteorology, Environment and Arid Land Agriculture, King Abdulaziz University, Jeddah 80208, Saudi Arabia

Full list of author information is available at the end of the article
}

michiganensis $(\mathrm{Cmm})$ is highly destructive, leading to severe economic losses (Sen et al. 2015). This infectious disease can spread rapidly and result in a severe loss in the productivity. The severity of the disease and yield losses depends on plant susceptibility and the environmental conditions (de León et al. 2011). Temperatures in the range $\left(25-28^{\circ} \mathrm{C}\right)$ and high humidity are optimal for symptom development (Sharabani et al. 2014). The disease develops most rapidly in young, succulent, and well-fertilized plants and with no current cure, when the spread of the disease occurs in a greenhouse or field, it is difficult to manage or eradicate (Montenegro et al. 2018). In Egypt, this disease was detected on tomato plants grown in certain newly reclaimed areas (Abd ElSayed 2002, 2003). To avoid the heavy application of pesticides in the production of vegetable crops, many biological strategies, such as natural products, antibiotic production, growth promotion, and competition for 
nutrients, have been suggested to protect the plants against pathogens (Aksoy et al. 2017).

Plant growth-promoting rhizobacteria (PGPR) are known for disease reduction and growth promotion in crops. This potentially attractive alternative disease management approach has become a common practice in many regions of the world (Amkraz et al. 2010). Bacillus spp. successfully been used before for controlling of plant pathogenic fungi and bacteria diseases (Kloepper and Ryu 2006). The fluorescent pseudomonads also, used for the control of many pathogens, i.e., soil-borne and some foliar diseases (Hashem and Abo-Elyousr 2011), which suppress plant pathogens either directly (Tjamos et al. 2004) or indirectly (Audenaert et al. 2002). Although significant control of plant pathogens has been demonstrated by PGPR in greenhouses' studies, results in the field have been inconsistent (Siddiqui 2005). One of the major challenges facing the success of these bacterial control agents (BCAs) in the field is the lack of an appropriate formulation (Kumar et al. 2014).

Efficiency of the formulated PGPR as biocontrol agents in controlling the bacterial wilt disease of tomato plants caused by Clavibacter michiganensis subsp. michiganensis was evaluated. The potential production of siderophores, hydrogen cyanide $(\mathrm{HCN})$, and indole acetic acid (IAA) by the BCAs and the PGPR formulation was assessed to establish the mode of their actions.

\section{Materials and methods}

\section{Pathogenic bacterium}

The virulent isolate of $C$. michiganensis subsp. michiganensis $(\mathrm{Cmm} 7)$ was obtained from the Department Plant Pathology, Assiut University, Egypt. This bacterium was previously isolated and identified, using biochemical methods (Holt et al. 1994). It was grown on yeast peptone glucose agar medium (YPGA) at $27 \pm 1{ }^{\circ} \mathrm{C}$ for 4 days, $\left(\right.$ YPGA; $\left[1^{-1}\right) 10 \mathrm{~g}$ peptone, $5 \mathrm{~g}$ yeast extract, $20 \mathrm{~g}$ dextrose, $15 \mathrm{~g}$ agar). For inoculation of tomato plants, $\mathrm{Cmm} 7$ cells were cultured in YPG liquid medium at $27 \pm 1{ }^{\circ} \mathrm{C}$ for $72 \mathrm{~h}$ with shaking at $150 \mathrm{rpm}$. The bacterial cell suspensions were centrifuged $(10,000 \times g$ for $8 \mathrm{~min})$, the bacterial cells re-suspended in a tap water, and density adjusted to $2 \times 10^{8} \mathrm{cfu} \mathrm{ml}^{-1}$.

\section{Antagonistic bacteria}

Ten bacterial isolates (BCAs) were recovery from the rhizosphere of healthy tomato plants grown in a field at Assiut, Egypt. The BCAs were maintained on slopes of King's $\mathrm{B}$ medium (KB; $\left[1^{-1}\right] 20 \mathrm{~g}$ proteose peptone, $1.5 \mathrm{~g}$ $\mathrm{K}_{2} \mathrm{HPO}_{4}, 1.5 \mathrm{~g} \mathrm{Mg}_{2} \mathrm{SO}_{4} .7 \mathrm{H}_{2} \mathrm{O}, 20 \mathrm{~g}$ agar) and LuriaBertani broth (LB; $\left[\mathrm{l}^{-1}\right] 10 \mathrm{~g}$ tryptone, $5 \mathrm{~g}$ yeast extract, $10 \mathrm{~g} \mathrm{NaCl}, 20 \mathrm{~g}$ agar), respectively, stored at $4{ }^{\circ} \mathrm{C}$. The activity of $10 \mathrm{BCAs}$ against $\mathrm{Cmm} 7$ was tested, using the agar well diffusion method, after Abo-Elyousr and El-
Hendawy (2008). The cell suspension of $\mathrm{Cmm} 7$ was grown over the surface of KB medium. The Petri dishes left to dry and then $0.05 \mathrm{ml}$ of an overnight culture of the isolated bacteria was placed into $9 \mathrm{~mm}$ wells. The Petri dishes were then incubated for 2 days at $27 \pm 1{ }^{\circ} \mathrm{C}$ before examination for inhibition zones. The experiment was repeated twice with four replicates per treatment. The bacterial isolates, which showed a high antagonistic ability against the pathogenic bacterium, were selected and identified according to their morphological and cultural biochemical tests (Schaad 1988 and Holt et al. 1994).

\section{Treatment of tomato plant and disease evaluation under greenhouse conditions \\ Tomato plants}

Tomato seeds cultivar Super Marmalade were provided by the Department of Vegetable, Assiut University, Egypt. The seeds were sown in 20-cm-diameter clay pots, containing a mixture of sand and soil $\left(1.4 \mathrm{w} \mathrm{w}^{-1}\right)$ at $2 \mathrm{~kg} \mathrm{pot}^{-1}$. All pots were placed in greenhouse at $30 \pm$ $5{ }^{\circ} \mathrm{C}, 68-80 \% \mathrm{RH}$, with $11 \mathrm{~h}$ of natural light and $13 \mathrm{~h}$ of darkness daily, and the plants were watered as required.

\section{Preparation of talc-based formulation of BCAs}

Four bacterial isolates were selected to be formulated, based on their activity against the pathogen in vitro. To prepare the bacterial control agent (BCA) formulation, the method of Vidhyasekaran and Muthamilan (1995) was adopted. Briefly, the isolate of BCA was grown on a liquid $\mathrm{KB}$ medium at $27 \pm$ $1{ }^{\circ} \mathrm{C}$ on a rotary shaker at $150 \mathrm{rpm}$ for $48 \mathrm{~h}$. A 400 $\mathrm{ml}$ aliquot of the bacterial suspension containing $108 \mathrm{cfu} \mathrm{m}^{-1}$ was mixed with $1 \mathrm{~kg}$ of the talc powder (dry-sterilized at $105^{\circ} \mathrm{C}$ for $12 \mathrm{~h}$ ), $15 \mathrm{~g} \mathrm{CaCO}_{3}$ (to adjust the $\mathrm{pH}$ to 7 ), and $10 \mathrm{~g}$ carboxymethylcellulose. After drying the formulation overnight under sterile conditions, it was packed into polypropylene bags.

\section{Inoculation of tomato plant and disease evaluation}

Tomato plants were removed from the pots, and the roots of plants were removed at $3 \mathrm{~cm}$ from the tips, using sterilized scissors. Roots with the adhering soil were placed in a suspension of $\mathrm{Cmm} 7\left(2 \times 10^{8} \mathrm{cfu} \mathrm{ml}^{-1}\right)$ for $5 \mathrm{~min}$. The plants in control treatments were treated with a tap water at the same time. After that, the plants were planted again in the original pots. The inoculated plants were placed under greenhouse conditions and watered with a tap water when needed. One month after inoculation, the vascular browning was evaluated, using a rating system from 0 to 3 according to Hassan and Buchenauer (2008).

The vascular browning index was calculated as follows: 
Vascular browning index (\%)

$$
=\frac{\text { Sum of ratings }(0-3) \text { scale }}{\text { Maximum possible score } \times \text { number of interlodes evaluated }} \times 100
$$

\section{Effect of BCAs on seedling vigor and seed germination in vitro}

Tomato seeds were immersed in a bacterial suspension containing $1 \times 10^{8} \mathrm{cfu} \mathrm{ml}^{-1}$ of each BCA and, as the controls; seeds were treated by the pathogen and water, respectively. All tubes were gently shaken for $1 \mathrm{~h}$ and then blot-dried, plated on wet blotters, and the germination tested by the filter paper method. A set of each treatment (containing 50 seeds) was replicated 3 times. The Vigor Index of the seeds calculated according to Abdul Baki and Anderson (1973):

$$
\begin{aligned}
\text { Vigor Index }= & (\text { mean shoot length }+ \text { mean root length }) \\
& \times \text { percentage of germination }
\end{aligned}
$$

\section{Effect of treatment with BCAs as a suspension or formulation on disease severity}

Treatment with BCAs Four bacterial control agents (BCAs) (Bacillus subtilis, B. amyloliquefaciens, Pseudomonas fluorescens, and $P$. aeruginosa) were used at the concentration of $2 \times 10^{8} \mathrm{cfu} \mathrm{ml}^{-1}$, and the formulation was used at $15 \mathrm{~g}$ per $\mathrm{kg}^{-1}$ seeds. Pathogen inoculation was carried out as mentioned above in "inoculation of tomato plants and disease evaluation." All pots with the treated and inoculated seedlings were placed under the greenhouse conditions as described previously, and the disease severity was recorded 1 month after inoculation. The experiment was repeated twice with four replicates. Each replicate consisted of two seedlings. Also, soil drenching with each BCA at $50 \mathrm{ml} \mathrm{pot}^{-1}$, individually, were applied to tomato plants (four true-leaf stages).

Determination of the bacterial pathogen in plants For the dilution plating method, samples of the lower stem internodes of the different treatments were taken 4 weeks after inoculation. Once the fresh weight was measured, the stem tissue was washed with tap water, surface-sterilized with 70\% ethanol and again washed with a sterile water. Plates were incubated for 5 days at $26^{\circ} \mathrm{C}$, and the number of bacterial colonies was counted (Abo-Elyousr and El-Hendawy 2008).

Fresh and dry weight determination Tomato seedlings from each treatment were removed and washed by water to remove any soil then blotted with tissue paper, and the fresh weight of shoots was determined. To determine the dry weight the shoots, they were dried at $60{ }^{\circ} \mathrm{C}$ for $72 \mathrm{~h}$.

\section{Production of siderophores, hydrogen cyanide, and indole acetic acid by the bacterial control agents Siderophore production}

The production of siderophores by PGPR species was assayed by the plate assay method, as described by Schwyn and Neilan (1987). After growing overnight, PGPR isolates $(10 \mu \mathrm{l})$ were spotted on Chrome Azurol S blue agar plates and incubated at $28 \pm 2{ }^{\circ} \mathrm{C}$ for $48 \mathrm{~h}$. A yellow-orange zone around the spotted colony was taken as a positive indication of siderophore production. The extent of siderophore biosynthesis was measured as the diameter of the zone developed (Alexander and Zuberer 1991).

\section{HCN production}

The potential of the efficient bioagents to produce hydrogen cyanide $(\mathrm{HCN})$ was assessed, as per the method of von Rohr et al. (2009). Whatman No. 1 filter paper pads were placed on the lids of the Petri plates, and the plates were sterilized. Tryptic soy agar medium amended with glycine $\left(4.4 \mathrm{~g} \mathrm{l}^{-1}\right)$ was sterilized and poured into the sterile plates. Each isolate $(24 \mathrm{~h}$ old) were streaked onto the medium. The filter paper padding in each plate was soaked by $2 \mathrm{ml}$ of sterile picric alkaline solution ( $2 \%$ sodium carbonate in $0.5 \%$ picric acid). The inoculated plates were sealed with parafilm to contain the gaseous metabolite produced by the antagonistic bacteria and to allow a chemical reaction with picric acid on the top. After incubation at $28 \pm 2{ }^{\circ} \mathrm{C}$ for 1 week, a color change of the filter paper was noticed, and the $\mathrm{HCN}$ production potential of the antagonistic bacteria was assessed.

\section{IAA production}

The production of indole acetic acid (IAA) by the BCAs was determined, as detailed elsewhere (Egamberdieva et al. 2008). Briefly, the tested isolates were inoculated in $\mathrm{KB}$ medium supplemented with $1.5 \% \mathrm{NaCl}$ and $\mathrm{Mg}_{2} \mathrm{SO}_{4}$ and incubated at $28 \pm 2{ }^{\circ} \mathrm{C}$ at $150 \mathrm{rpm}$. After cultivation for 3 days, aliquots of bacterial cultures were centrifuged at $13,000 \mathrm{rpm}$ for $10 \mathrm{~min}$. A 2-ml aliquot of the supernatant was transferred to a tube with 2 drops of orthophosphoric acid and $4 \mathrm{ml}$ of Salkowski reagent. The mixture was incubated at room temperature for $25 \mathrm{~min}$ and recorded as positive, if a pink color developed.

\section{Statistical analysis}

Four replicates per treatment were used and the experiments were performed twice with a completely randomized design. Because the analyses showed insignificant 


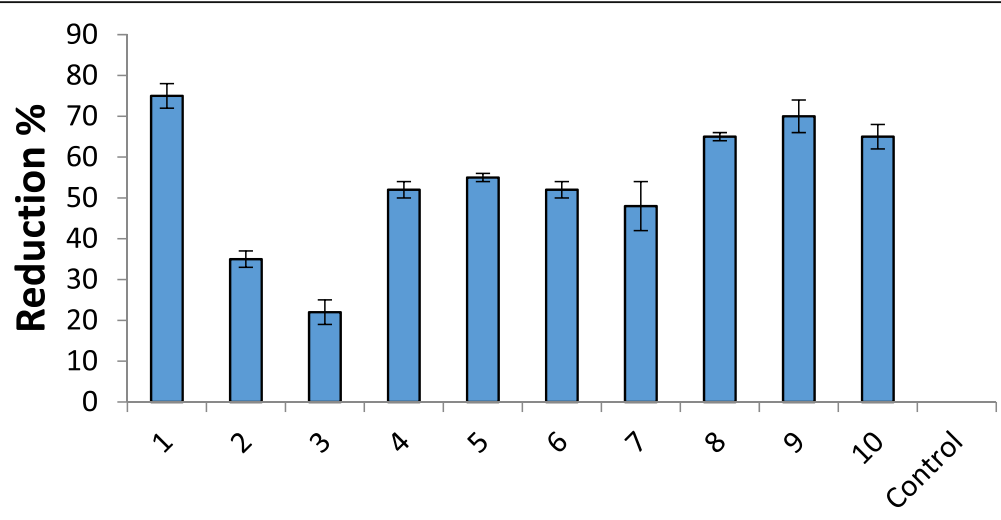

Isolates No.

Fig. 1 Effect of different isolates of bacterial bioagents on bacterial growth of Clavibacter michiganensis subsp. michiganensis. Means of standard deviation for eight plants per treatment are shown

interaction between the two experiments, results were combined for final analysis. The data were evaluated by analysis of variance, using SPSS 10.0 (SPSS, Chicago, IL, USA). Differences between treatment means were determined, using the least significant difference (LSD) test $(P<0.05)$.

\section{Results and discussion}

\section{In vitro antagonistic activity}

Ten isolates of bacteria were isolated from the rhizosphere of healthy tomato plants and tested for their antagonistic potentiality against $\mathrm{Cmm} 7$ in vitro. All isolates were able to restrict the growth of $\mathrm{Cmm}$; the maximum inhibition zone was obtained by isolate 1 (Fig. 1), followed by isolates 9, 8, and 10, respectively. The lowest effect was recorded by isolates 2 and 3, while the remaining isolates produced a moderate impact on the growth of the pathogen. Based on these results, the best four isolates, namely, $B$. subtilis $1, B$. amyloliquefaciens 9, P. fluorescens 8 , and P. aeruginosa 10, were selected as the best BCAs to complete the subsequent experiments.

Ten bacteria, isolated from the rhizosphere of tomato plants, were evaluated against $C m m 7$. The results showed that all tested isolates of the bacterial BCAs antagonized $\mathrm{Cmm} 7$ on $\mathrm{KB}$ medium, while $B$. amyloliquefaciens was the most effective one. This result agrees with the findings of Amkraz et al. (2010), who approved P. fluorescens as an antagonistic microorganism against $\mathrm{Cmm}$ in vitro. Bacterial wilt of tomato caused by $\mathrm{Cmm} 7$ has become a serious disease for tomato production under a protected cultivation system (Abd El Ghafar and Mosa 2001). Many bacteria (e.g., Bacillus, Pseudomonas, and Agrobacterium) have been used as BCAs to treat soil or plants (Fravel 2005).

The ability of PGPR, as antagonists, to inhibit pathogen growth and to produce secondary metabolites has been claimed to be important for biological control (ElFawy et al. 2018). Chandra et al. (2017) reported that a growth inhibition on agar media might be due to the secretion of chemicals, such as antibiotics or antibioticlike substances. Fluorescent pseudomonad strains on KB and potato dextrose agar media produced a diverse array of inhibitory compounds (siderophores), which inhibited the growth of phytopathogens (Kang et al. 2010). Strains of PGPR stimulated plant growth and increased yield indirectly by their aggressive colonization of the root system. Production of both antibiotics and siderophores has

Table 1 In vitro effect of bacterial bioagents on seed germination and seedling vigor of tomato

\begin{tabular}{lllll}
\hline Treatments & Germination \% & MSL (Cm) & MRL $(\mathrm{Cm})$ & \\
\hline Bacillus amyloliquefaciens & $90 \mathrm{a}$ & $1.2 \mathrm{a}$ & $5.2 \mathrm{a}$ & \\
Bacillus subtilis & $75 \mathrm{~b}$ & $1.0 \mathrm{~b}$ & $4.0 \mathrm{c}$ & \\
Pseudomonas fluorescens & $77 \mathrm{~b}$ & $0.9 \mathrm{~b}$ & $376.0 \mathrm{a}$ & $375.0 \mathrm{c}$ \\
Pseudomonas aeruginosa & $70 \mathrm{c}$ & $1.0 \mathrm{~b}$ & $369.6 \mathrm{c}$ \\
Control with Cmm7 & $60 \mathrm{~d}$ & $0.6 \mathrm{c}$ & $4.0 \mathrm{c}$ & $350.0 \mathrm{~d}$ \\
Control (water) & $89 \mathrm{a}$ & $1.0 \mathrm{~b}$ & $2.8 \mathrm{~d}$ & $204.0 \mathrm{e}$ \\
\hline
\end{tabular}

MRL mean root length, MSL mean shoot length, VI Vigor Index

Values in the same column followed by different letters indicate significant differences among treatments according to LSD $(P<0.05)$ 
Table 2 Effect of bacterial bioagents and their formulation on number of bacteria in plant under greenhouse conditions

\begin{tabular}{lll}
\hline Treatments & Method of application & Bacterial numbers (cfu/g stem tissue) after 2 weeks from inoculation \\
\hline Bacillus amyloliquefaciens & Cell suspension & $3 \times 10^{2 \mathrm{~cd}}$ \\
Bacillus subtilis & Formulation & $3 \times 10^{2 \mathrm{~cd}}$ \\
& Cell suspension & $4 \times 10^{3 \mathrm{ba}}$ \\
Pseudomonas fluorescens & Formulation & $1 \times 10^{2 \mathrm{de}}$ \\
& Cell suspension & $3 \times 10^{4 \mathrm{bc}}$ \\
Pseudomonas aeruginosa & Formulation & $5 \times 10^{3 \mathrm{bc}}$ \\
& Cell suspension & $2 \times 10^{2 \mathrm{~cd}}$ \\
Control & Formulation & $2 \times 10^{3 \mathrm{~cd}}$ \\
& Infected & $5 \times 10^{6 \mathrm{a}}$ \\
Vealthy & $0.0^{\mathrm{f}}$
\end{tabular}

Values in the column followed by different letters indicate significant differences among treatments according to LSD $(P<0.05)$

been cited as a factor associated with the ability of PGPR to displace or exclude soil-borne pathogens and deleterious rhizosphere microorganisms (Ramadan et al. 2016).

\section{Effect of BCAs and their formulations on seed} germination and seedling vigor of tomato plants

All treatments increased the percentage of germination, and the treatment with $B$. amyloliquefaciens was the best one as it increased the seed germination up to $90.0 \%$, followed by $P$. fluorescens and B. subtilis. Among the four bacteria, $P$. aeruginosa showed the lowest increase in the seed germination (70\%). The treatment with $B$. amyloliquefaciens increased the mean shoot length, mean root length, and Vigor Index, most effectively, followed by the other isolates (Table 1). Massive systemic colonization of tomato's xylem vessels by the pathogenic $\mathrm{Cmm}$ cells was reported by Hassan and AboElyousr (2013), who detected its titer as $10^{9}$ cells $\mathrm{g}^{-1}$ tissue. Obtained results showed that the treatment of tomato plants with PGPR effectively retarded multiplication of $\mathrm{Cmm} 7$ cells in xylem tissue 2 weeks after inoculation than the control. We assume that PGPR could compete with the pathogenic bacteria to colonize the internal vascular tissue and protect the plants from the pathogen colonization.

\section{Effect of BCAs and their formulations on the $\mathrm{Cmm7}$ population in tomato seedlings under greenhouse conditions}

The results presented in Table 2 showed that treatment with any of the four BCAs significantly reduced the pathogen number in tomato seedlings than in the infected and untreated control. The formulated B. subtilis and $P$. aeruginosa exhibited the best reductions (Table 2). The highest number of $\mathrm{Cmm} 7$ occurred in the infected and untreated control plants.

\section{Effect of BCAs and their formulations on disease} reduction under greenhouse conditions

All treatments significantly reduced the disease severity of bacterial wilt of tomato plants than the infected control. The highest reduction was achieved in tomato seedlings treated with the formulated B. amyloliquefaciens, followed by $P$. aeruginosa, and the lowest decline was obtained when plants were treated by the P. fluorescens suspension and its formulated concoction, followed by application of the B. subtilis suspension (Table 3). The appropriate formulation of the BCA could improve the biocontrol efficiency (Lima et al. 2014). Obtained results showed that the BCAs, either in suspension or formulated, significantly decreased the severity of bacterial wilt than in the infected control. In addition, in most cases, the formulations enhanced the efficiency of the antagonistic bacteria. The results concur with previous works that confirmed the successful application of BCA against $\mathrm{Cmm}$ under glasshouse conditions (Abo-Elyousr and ElHendawy 2008 and Boudyach et al. 2010). Kasselaki et

Table 3 Effect of bacterial bioagents and their formulation on disease severity (\%) under greenhouse conditions

\begin{tabular}{lll}
\hline Treatments & Method of application & Disease severity (\%) \\
\hline Bacillus amyloliquefaciens & Cell suspension & $26 \mathrm{de}$ \\
& Formulation & $19 \mathrm{f}$ \\
Bacillus subtilis & Cell suspension & $35 \mathrm{c}$ \\
& Formulation & $29 \mathrm{~d}$ \\
Pseudomonas fluorescens & Cell suspension & $45 \mathrm{~b}$ \\
& Formulation & $35 \mathrm{c}$ \\
Pseudomonas aeruginosa & Cell suspension & $30 \mathrm{~d}$ \\
& Formulation & $25 \mathrm{de}$ \\
Control & Infected & $75 \mathrm{a}$ \\
& Healthy & 00 \\
\hline
\end{tabular}

Values in the column followed by different letters indicate significant differences among treatments according to LSD $(P<0.05)$ 
al. (2011) reported that seed treatment with both Pseudomonas and Bacillus strains decreased the incidence of bacterial canker in the field. Bacillus subtilis and Rhodosporidium diobovatum have also been applied as effective BCAs against $\mathrm{Cmm}$ in the field (Hassan and Buchenauer 2008; Enebe and Babalola 2018and Nandi et al. 2018).

\section{Effect of BCAs and their formulations on the fresh and} dry weight of tomato shoots under greenhouse

\section{conditions}

Fresh and dry shoot weights of the plants infected with $\mathrm{Cmm} 7$ were significantly lower than that of the healthy control. All treatments significantly increased the fresh and dry weights of tomato shoots than the infected control (Table 4). Treatment with the formulated B. amyloliquefaciens was the most effective, increasing both the fresh and dry weights of shoots to 118 and $10.1 \mathrm{~g}$ plant $^{-1}$, respectively. Whereas $P$. fluorescens was the lowest than the other treatments but still significantly higher than the infected control.

\section{Siderophore, $\mathrm{HCN}$, and IAA production by BCAs}

The results indicated that the four antagonistic bacteria produced siderophores at different levels (Fig. 2a). As reflected by the diameter of the yellow zone surrounding the bacterial growth, B. subtilis and B. amyloliquefaciens showed substantial amounts of siderophore production, followed by $P$. fluorescens. Conversely, $P$. aeruginosa showed the least zone of inhibition. In vitro, $\mathrm{HCN}$ production by the BCAs. As illustrated in Fig. 2b, not all isolates could produce $\mathrm{HCN}$. Among them, B. subtilis was scored as moderate $(++)$, while $B$. amyloliquefaciens and $P$. fluorescens were graded as weak $(+)$. Three out of the four tested
Table 4 Effect of some bacterial bioagents and their formulation on fresh and dry weight of shoots under greenhouse conditions

\begin{tabular}{llll}
\hline Treatments & Method of application & FW & DW \\
\hline Bacillus amyloliquefaciens & Cell suspension & $115 \mathrm{~b}$ & $9.2 \mathrm{a}$ \\
& Formulation & $118 \mathrm{a}$ & $10.1 \mathrm{a}$ \\
Bacillus subtilis & Cell suspension & $101 \mathrm{e}$ & $8.2 \mathrm{bc}$ \\
& Formulation & $105 \mathrm{~d}$ & $8.5 \mathrm{bc}$ \\
Pseudomonas fluorescens & Cell suspension & $99 \mathrm{de}$ & $7.1 \mathrm{~cd}$ \\
& Formulation & $95 f$ & $7.5 \mathrm{~cd}$ \\
Pseudomonas aeruginosa & Cell suspension & $111 \mathrm{c}$ & $9.1 \mathrm{a}$ \\
& Formulation & $118 \mathrm{a}$ & $10.0 \mathrm{a}$ \\
Control & Infected & $67 \mathrm{~g}$ & $6.0 \mathrm{de}$ \\
& Healthy & $120 \mathrm{a}$ & $10.0 \mathrm{a}$ \\
\hline
\end{tabular}

FW fresh weight, DW dry weight. Fresh and dry weight are expressed as $\mathrm{g}$ plant ${ }^{-1}$

Values in the same column followed by different letters indicate significant differences among treatments according to LSD $(P<0.05)$

bacteria could produce IAA (Fig. 2c). B. subtilis showed the highest production $(+++)$, followed by $B$. amyloliquefaciens and $P$. fluorescens $(++)$. P. aeruginosa was scored as negative (-) for $\mathrm{HCN}$ and IAA, given the absence of color development in both tests.

The results approved the production of siderophores by the four tested bacterial species. This result confirmed their efficiency as BCAs against the pathogen because siderophores directly stimulate the biosynthesis of other antimicrobial compounds by increasing the availability of these minerals to the bacteria, which, in turn, suppresses the growth of pathogenic organisms, via functioning as stress factors in inducing host resistance (Wahyudi et al. 2011). Dimkpa et al. (2009) reported that siderophore production is an important attribute of

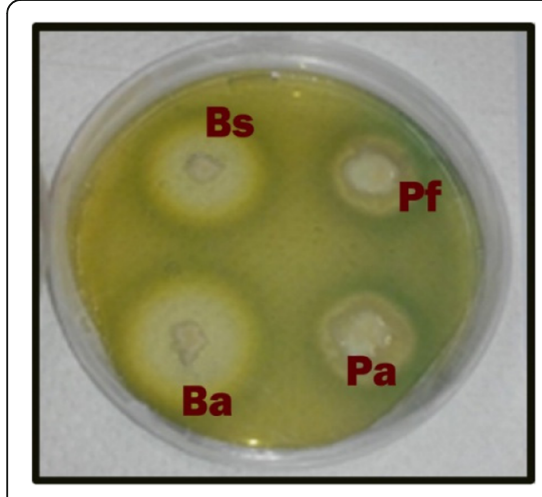

a

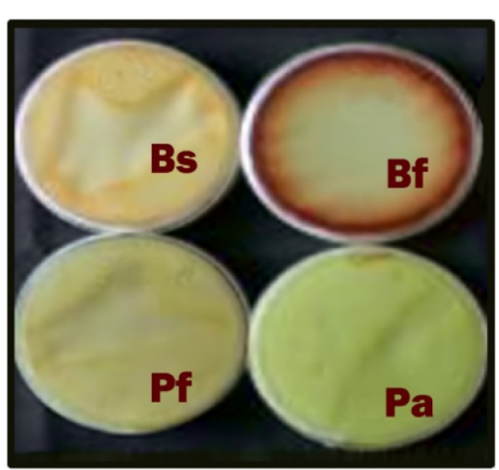

b

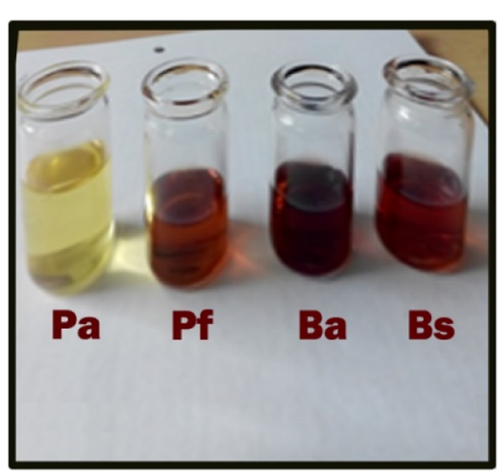

$\mathrm{C}$

Fig. 2 Detection of siderophores, indole acetic acid and HCN production by certain bioagents. Wherase Bs = Bacillus subtilis, Ba =Bacillus amyloliquefaciens, $\mathrm{Pf}=$ Pseudomonas fluorescens, and $\mathrm{Pa}=$ Pseudomonas aeruginosa a Production of siderophores with yellow halo produced around the bacterial growth. b No color change (-), no HCN production; brownish coloration (+), weak production; brownish to orange (++), moderate production; orange to reddish brown $(+++)$, strong production. c Record of the developed pink color means indole acetic acid production 
rhizobacteria for survival and growth in a competitive ecosystem having iron as a limiting factor. B. subtilis, $B$. amyloliquefaciens, and $P$. fluorescens produced variable amounts of siderophores, but B. subtilis was superior. IAA may be involved in the epiphytic fitness of PGPR. The secretion of IAA by the bacteria may modify the micro-habitats of epiphytic bacteria by increasing nutrient leakage of plant cells and enhancing nutrient availability (Bashan et al. 2004). PGPR stimulate plant growth by the mechanisms of production of phytohormones, which are usually believed to be involved in plant growth promotion (Glickmann and Dessaux 1995) and increase the number of root hairs and lateral roots (Okon and Kapulnik 1986). Gopalakrishnan et al. (2012) stated that the Pseudomonas is a growth-promoting bacterium responsible for cell elongation and root developments.

The results showed that the variable affinity of $B$. subtilis, B. amyloliquefaciens, and P. fluorescens could produce HCN. The production of HCN by PGPR is an important trait in controlling the disease (Cattelan et al. 1999). It has been well documented that rhizobacterial strains affect the plant health indirectly by the production of secondary metabolites, including cell wall degrading enzymes, antibiotics, siderophores, and $\mathrm{HCN}$ metabolites, and prevent the damaging effect of pathogens (Glick 2015). Obtained results are supported by the findings of Tripathi et al. (2005) who confirmed the production of IAA, siderophores, and HCN by Bacillus spp. and P. fluorescence. Benali et al. (2014) mentioned that $P$. fluorescens strains produced several siderophores, such as pyoverdine (pseudobactin), pyochelin, and salicylic acid.

\section{Conclusion}

The PGPR (B. subtilis, B. amyloliquefaciens, P. fluorescens, and $P$. aeruginosa), and their formulations, successfully controlled the wilt and canker disease of tomato caused by $\mathrm{Cmm}$, in vitro and under greenhouse conditions, and enhanced the growth parameters of the plants. The results can recommend the application of the formulations of the antagonistic bacteria (PGPR) on a fieldscale, as a safe and eco-friendly method to protect the tomato crop against the bacterial wilt disease and to enhance the productivity of this important crop.

\section{Abbreviation \\ BCAs: Bacterial control agents; Cmm: Clavibacter michiganensis subsp. Michiganensis; HCN: Hydrogen cyanide; IAA: Indole acetic acid; PGPR: Plant growth-promoting rhizobacteria}

\section{Acknowledgements}

Not applicable.

\section{Authors' contributions}

KA participated in the planning and designing of the experiments, implementation of the experiments, and writing of the manuscript. HK helped in the bacterial identification, analyzing the data, and writing the manuscript. $\mathrm{MH}$ participated in the planning and implementation of the experiments, sampling, lab work, and writing the draft. SA participated in the planning and implementation of the experiments, and writing the draft. YM participated in the implementation of the experiments, sampling, lab work, and collecting the data. All authors read and approved the final manuscript.

\section{Funding}

The authors extend their appreciation to the Deanship of Scientific Research at King Khalid University for funding this work through a research groups program under grant number R.G.P. 1/61/39.

\section{Availability of data and materials}

Not applicable.

\section{Ethics approval and consent to participate}

This manuscript is in accordance with the guide for authors available on the journal's website. Also, this work has not been published previously and is approved by all authors and host authorities.

Consent for publication

All authors approve to the publication.

\section{Competing interests}

The authors declare that they have no competing interests.

\section{Author details}

${ }^{1}$ Faculty of Agriculture, Plant pathology Department, Assiut University, Assiut 71526, Egypt. ${ }^{2}$ Department of Arid Land Agriculture, Faculty of Meteorology, Environment and Arid Land Agriculture, King Abdulaziz University, Jeddah 80208, Saudi Arabia. ${ }^{3}$ Faculty of Science, Biology Department, King Khalid University, Abha, Saudi Arabia. ${ }^{4}$ Faculty of Science, Botany and Microbiology Department, Assiut University, Assiut, Egypt.

Received: 13 May 2019 Accepted: 6 August 2019

Published online: 20 August 2019

\section{References}

Abd El Ghafar NY, Mosa AA (2001) Integration between biological and chemical treatment to control bacterial spot disease of tomato. Egypt J Phytopathol 29:33-45

Abd El-Sayed WM (2002) Bacterial canker of tomato and its biological control. Egypt J Appl Sci 17:39-56

Abd El-Sayed WM (2003) Integration between biological and chemical treatment to control bacterial canker disease of tomato. Arab Univ. J Agric Sci, Ain Shams Univ., Cairo. 11:803-816

Abdul Baki AA, Anderson JD (1973) Vigour determination in soybean seed by multiple criteria. Crop Sci 13:630-633

Abo-Elyousr KAM, El-Hendawy HH (2008) Integration of Pseudomonas fluorescens and acibenzolar-S-methyl to control bacterial spot disease of tomato. Crop Protec 27:1118-1124

Aksoy HM, Kaya Y, Ozturk M, Secgin Z, Onder H, Okumus A (2017) Pseudomonas putida - induced response in phenolic profile of tomato seedlings (Solanum lycopersicum L.) infected by Clavibacter michiganensis subsp. michiganensis. Biol Control 105:6-12

Alexander BD, Zuberer DA (1991) Use of chrome Azurol S reagent to evaluate siderophore production by rhizosphere bacteria. Biology Fertil Soils 12:39-45

Amkraz N, Boudyach EH, Boubaker H, Bouizgarne B, Aoumar AAB (2010) Screening for fluorescent pseudomonades, isolated from the rhizosphere of tomato, for antagonistic activity toward Clavibacter michiganensis subsp. michiganensis. World J Microbio Biotechnol 26(6):1059-1065

Audenaert K, Pattery T, Cornelis P, Höfte M (2002) Induction of systemic resistance to Botrytis cinerea in tomato by Pseudomonas aeruginosa 7NSK2: role of salicylic acid, pyochelin, and pyocyanin. Mol Plant Microbe Interact 15: $1147-1156$

Bashan Y, Holguin G, De-Bashan LE (2004) Azospirillum plant relationships: physiological, molecular, agricultural and environmental advances. Can J Microbiol 50:521-577

Benali S, Mohamed B, Eddine HJ (2014) Virulence strategies of phytopathogenic bacteria and their role in plant disease pathogenesis. Afr J Microbiol Res 8(30):2809-2815 
Boudyach EH, Fatmi M, Akhayat O, Benizri E, Aoumar AAB (2010) Selection of antagonistic bacteria of Clavibacter michiganensis subsp. michiganensis and evaluation of their efficiency against bacterial canker of tomato. Biocont Sci Tech 11:141-149

Cattelan AJ, Hartel PG, Fuhrmann JJ (1999) Screening for plant growth promoting rhizobacteria to promote early soybean growth. Soil Sci Soc Am J 63:1670-1680

Chandra H, Bishnoi P, Yadav A, Patni B, Prakash AM, Nautiyal AR (2017) Antimicrobial resistance and the alternative resources with special emphasis on plant-based antimicrobials_a review. Plants 6:16. https://doi.org/10.3390/ plants6020016

de León L, Siverio F, López MM, Rodríguez A (2011) Clavibacter michiganensis subsp. michiganensis, a seed born tomato pathogen: healthy seeds are still the goal. Plant Dis 95(11):1328-1339

Dimkpa CO, Merten D, Svatos A, Buchel G, Kothe E (2009) Metal-induced oxidative stress impacting plant growth in contaminated soil is alleviated by microbial siderophores. Soil Biol Biochem 41(1):154-162

Egamberdieva D, Kamilova F, Validov S, Gafurova L, Kucharova Z, Lugtenberg B (2008) High incidence of plant growth-stimulating bacteria associated with the rhizosphere of wheat grown on salinated soil in Uzbekistan. Environ Microbiol 10(1):1-9. https://doi.org/10.1111/j.1462-2920.2007.01424.x

El-Fawy, M.M., R.M. El-Sharkawy, and K.A.M. Abo-Elyousr, 2018. Evaluation of certain Penicillium frequentans isolates against Cercospora leaf spot disease of sugar beet.Egypt J Biolog Pest Cont, 28:49 DOI: https://doi.org/10.1186/s4193 8-018-0053-0

Enebe MC, Babalola OO (2018) The influence of plant growth-promoting rhizobacteria in plant tolerance to abiotic stress: a survival strategy. Appl Microbiol Biotechnol 102(18):7821-7835

Fravel DR (2005) Commercialization and implementation of biocontrol. Annu Rev Phytopathol 43:337-359

Glick BR (2015) Beneficial plant-bacterial interactions. Modulating Phytohormone levels. Springer international publishing, Switzerland. https://doi.org/10.1007/ 978-3-319-13921-0

Glickmann E, Dessaux Y (1995) A critical examination of the specificity of the Salkowski reagent for indoleic compounds produced by phytopathogenic bacteria. Appl Environ Microbiol 61:793-796

Gopalakrishnan S, Upadhyaya HD, Vadlamudi S, Humayun P, Vidya MS, Alekhya G, Singh A, Vijayabharathi R, Bhimineni RK, Seema M, Rathore A (2012) Plant growth - promoting traits of biocontrol potential bacteria isolated from rice rhizosphere. PMC 1(1):71

Hashem M, Abo-Elyousr KAM (2011) Management of the root-knot nematode Meloidogyne incognita on tomato with combinations of different biocontrol organisms. Crop Protect 30:285-292

Hassan AEM, Buchenauer H (2008) Enhanced control of bacterial wilt of tomato by DL-3-aminobutyric acid and the fluorescent Pseudomonas isolate CW2. J Plant Dis Protect 115. https://doi.org/10.1007/BF03356264

Hassan MAE, Abo-Elyousr KAM (2013) Activation of tomato plant defense responses against bacterial wilt caused by Ralstonia solanacearum using DL3-aminobutyric acid (BABA). Eur J Plant Pathol 136:145-157

Holt G, John D, Bergey H (1994) Bergey's manual of determination bacteriology. Eds Williams and Wilkinc, Baltimore, 787

Jones JB, Jones JP, Stall RE, Zitter TA (1991) Compendium of tomato diseases. APS Press, St. Paul

Kang BG, Kim WT, Yun HS, Chang SC (2010) Use of plant growth promoting rhizobacteria to control stress responses of plant roots. Plant Biotechnol 4: 179-183

Kasselaki AM, Goumas D, Tamm L, Fuchs J, Cooper J, Leifert C (2011) Effect of alternative strategies for the disinfection of tomato seed infected with bacterial canker (Clavibacter michiganensis subsp. michiganensis). NJAS Wageningen. J life Sci 58:145-147

Kloepper JW, Ryu CM (2006) Bacterial endophytes as elicitors of induced systemic resistance. In: Schulz B, Boyle C, Siebern T (eds) . Microbial root endophytes. Springer-Verlag, Heildelberg, pp 33-51

Kumar S, Thakur M, Rani A (2014) Review trichoderma: mass production, formulation, quality control, delivery and its scope in commercialization in India for the management of plant diseases. Afr J Agric Rese 9:3838-3852. https://doi.org/10.5897/AJAR2014.9061

Lima JR, Viana FMP, Lima FA, Pieniz V, Gonçalves LRB (2014) Efficiency of a yeastbased formulation for the biocontrol of postharvest anthracnose of papayas. Summa Phytopatho 40:203-211
Montenegro I, Madrid A, Cuellar M, Seeger M, Alfaro JF, Besoain X, Martínez J, Ramirez I, Olguín Y, Valenzuela M (2018) Biopesticide activity from drimanic compounds to control tomato pathogens. Molecules. 23:2053

Nandi M, Macdonald J, Liu P, Weselowski B, Ze-Chun Y (2018) Clavibacter michiganensis ssp. michiganensis: bacterial canker of tomato, molecular interactions and disease management Molecul. Plant Pathol 19:2036-2050

Okon Y, Kapulnik Y (1986) Development and function of Azospirillum inoculated roots. Plant soil 90:3-16

Ramadan EM, Ahmed AA, Hassan EA, Saber FM (2016) Plant growth promoting rhizobacteria and their potential for biocontrol of phytopathogens Afr. J Microbiol Res 10(15):486-504

Regassa D, Tigre W, Shiferaw A (2016) Tomato (Lycopersicon esculentum mill.) varieties evaluation in Borana zone, Yabello district, southern Ethiopia. J. Plant Breed Crop Scie 8(10):206-210

Schaad NW (1988) Identification schemes. In: Schaad NW (ed) Laboratory guide of identification of plant pathogenic bacteria, 2nd edn. Press, St. Paul, Minn pp 1-15

Schwyn BJB, Neilan OS (1987) Universal chemical assay for the detection and determination of Siderophores. Anal Biochem 160:47-56

Sen Y, van der Wolf J, Visser RGF, van Heusden S (2015) Bacterial canker of tomato: current knowledge of detection, management, resistance, and interactions. Plant Dise 99(1):4-13

Sharabani G, Manulis-Sasson S, Chalupowicz L, Borenstein M, Shulhani R, Lofthouse M (2014) Temperature atthe early stages of Clavibacter michiganensis subsp. michiganensis infection affects bacterial canker development and virulence gene expression. Plant Pathol 63(5):1119-1129

Siddiqui ZA (2005) PGPR: prospective biocontrol agents of plant pathogens. In: Siddiqui ZA (ed) PGPR: biocontrol and biofertilization. Springer, Dordrecht

Tjamos EC, Tsitsigiannis DI, Tjamos SE, Antoniou PP, Katinakis P (2004) Selection and screening of endorhizosphere bacteria from solarized soils as biocontrol agents against Verticillium dahliae of solanaceous hosts. Eur J Plant Pathol 110:35-44

Tripathi HMP, Munot Y, Shouch JM, Meyer GR (2005) Functional characterization of siderophore-producing lead- and cadmium-resistant Pseudomonas putida KNP9 Curr. Microbiol. 5:233-237

Vidhyasekaran P, Muthamilan M (1995) Development of formulations of Pseudomonas fluorescens for control of chickpea wilt. Plant Dis 79:782-786

von Rohr MR, Furrer G, Brandl H (2009) Effect of iron and phosphate on bacterial cyanide formation determined by methemoglobin in two-dimensional gradient microcultivations. J Microbiol Methods 79:71-75. https://doi.org/10.1 016/j.mimet.2009.08.008

Wahyudi AT, Astuti RP, Widyawati A, Meryandini AA, Nawangsih AA (2011) Characterization of Bacillus sp. strains isolated from rhizosphere of soybean plants for their use as potential plant growth for promoting rhizobacteria. J Microbiol Antimicrob 3(2):34-40

\section{Publisher's Note}

Springer Nature remains neutral with regard to jurisdictional claims in published maps and institutional affiliations.

\section{Submit your manuscript to a SpringerOpen ${ }^{\circ}$ journal and benefit from:}

- Convenient online submission

- Rigorous peer review

- Open access: articles freely available online

High visibility within the field

- Retaining the copyright to your article

Submit your next manuscript at $>$ springeropen.com 